\title{
worldview
}

\section{THE GREAT SOCIETY AND FOREIGN AFFAIRS}

President Johnson's State of the Union message was buoyant in its breadth, its aspiration and its measured optimism. It was the first comprehensive statement of the President's overall intentions and expectations, of his design or vision, of what we have come to call the "philosophy" of any Administration.

What the President envisaged for our domestic policies had, of course, been suggested by many of his addresses and actions almost from the day of his accession, but even. here there were some innovations. What had been less clear-what had been in fact decidedly cloudy-was the shape of the new President's foreign policy. It is not an area in which he showed special interest over the years, developing along the way a record that would indicate paths for the future. Nor did he have much opportunity for public expression of personal judgments as Vice President. For these reasons, the indications of how he would shape our foreign policy were of special interest, both at home and abroad.

In the most general terms the great burden of : the United States is to make clear, first to itself and then to others, its role as a leader in world affairs. This burden and its concomitant responsibilities rest primarily on the President. In Harry Truman's phrase, "the buck stops here." In this year of 1965 , and in the years immediately ahead, the great task will be to find patterns for order among a number of situations which give rich promise of exploding into chaos. The challenges which our country taces are great and many of the familiar counters have shifted in recent months.

Aside from the change in our own leadership, the most expected and potentially significant change was, of course, that in the Soviet Union. Where Khrushchev ywas, there are now Kosygin and Brezhnev. The position once filled by Nehru now belongs to Lal Shastri. After a poriod of thirteen years a Labor government, under the leadership of Harold Wilson, directs the fortunes of Britain. Tshombe is Premier of one of the real tinder boxes of international affairs; one hesitates to name the leadership of South Vietnam in any statement that will not be read within the next several days. To lend some semblance of stability to these indications of shifting patterns, Charles de Gaulle remains as steadfast as many of his policies.

$\bullet$

As he moved rapidly over the surface of our foreign relations President Johnson exhibited characteristics which familiar observers have come to recognize as distinctly his. Where there exist friendly ties between our government and others he emphasized them, where there are tensions he minimized or slighted them, where there are great differences and antagonisms he suggested that they might be lessened. Insofar as a consensus could be reached on any particular issue he sought it. But all this was based on the assumption, implicit but apparent throughout his address, that the United States has great resources-technical, military, economic, political, spiritual-and the determination to use these resources in the pursuit of proper goals.

The time of testing these goals and resources is upon us. Indeed it was so even as the President delivered his address. Conscious of Dean Acheson's timely speech on ethics in international affairs-a speech that had much to recommend it -workloiew will direct its attention in the coming months to these goals and their implementation, particularly as they are tested in, for example, crises such as those of the Congo and South Vietnam, in the attempts to resolve problems of NATO, and in the attempts to control the growth of nuclear systems. As a prelude to what must be a continuing examination, worldview will, in its next issue, review Dean Acheson's speech.

J. F. 